\title{
壁面過熱度を考慮した噴霧-壁面干渉モデル*
}

\author{
千田二郎*1, 高橋 知 宏*2, 田中智 之草 \\ 李 奇 衡*4, 藤 本 元 $^{* 1}$
}

\section{Spray-Wall Interaction Model Considering Superheating Degree of the Wall Surface}

\author{
Jiro SENDA*5, Tomohiro TAKAHASHI, Tomoyuki TANAKA, \\ Ki-Hyung Lee and Hajime FUJIMOTO \\ ${ }^{* 5}$ Doshisha University, Dept. of Mechanical Engineering, \\ Kyotanabe, Kyoto, 610-0321 Japan
}

\begin{abstract}
In this study, a new concept is proposed in order to simulate the behavior of multicomponent fuel spray impinging on a hot surface. Here, distillation curve of the fuel is considered to describe the vaporization property of each component in gas oil, since the superheating degree of the surface, defined by the temperature difference between the wall surface and the fuel saturated temperature, affects the solid-liquid boiling state. At the first, some impinging sprays structured by single component fuel are calculated to confirm the difference of vaporizing characteristics and impinging behavior in each fuel. Secondary, the spray impingement submodel is made. In this model, the difference of droplet breakup, reflection and dispersion process with the difference of boiling state is considered based on several experimental results of impinging droplet on a hot wall. This new submodel is incorporated into KIVA-II code. And the results calculated by this model are compared with that by KIVA-II original code.
\end{abstract}

Key Words: Diesel Engine, Fuel, Modeling, Boiling, Fuel Injection, Wall Impingement, Multicomponent Fuel, Saturated Temperature, Distillation, Simulation

\section{1. 緒言}

筆者らはこれまで非定常ディーゼル噴霧に対して常 温・高圧場(1)および高温・高圧場(2)(3)にお拈る平板壁面 衝突挙動について実験解析を行なってきた。その一方

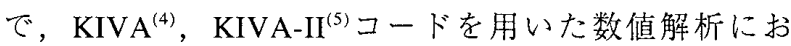
いては，噴霧一壁面干渉に関するサブモデルを考案し てきた。ここでは，燃焼室の壁面温度が低い条件と高 い条件を考虑して，それぞれ壁面上での液膜形成過程 と衝突液滴の沸騰分裂過程を考慮したモデルを提案し た(6).(7)。また，衝突液滴の持つエネルギにより，液滴 が壁面に衝突する際のWeber数が低い場合と高い場合 に分類し，液滴の壁面衝突による分裂・飛散現象，液 滴同士の干渉効果, 液膜の形成過程, 液滴と液膜の干 渉効果, 壁面からの熱伝達を考慮したモデリングを行

\footnotetext{
* 原稿受付 1999 年 6 月 18 日.

*1 正員, 同志社大学工学部 (画 610-0321 宗田辺市多久羅都谷 1 $-3)$.

*2 同志社大学大学院.

*3 学生買, 同志社大学大学院.

*4 漢陽大学校 (函 133-791 ソウル市城東区杏堂洞 17, 大韓民 国)

E-mail : jsenda@mail.doshisha.ac.jp
}

なった(8),(9). しかし，これらの研究は多成分燃料であ る軽油の一成分であるn-トリデカンを代表然料として 行なってきたため，解析結果を実際の機関で使用され る軽油噴霧に適用するには無理があると考えられる。 そのため, 今後は実機関で使用される燃料が多数の成 分より構成されていることを念頭に置いた研究が要求 される。

軽油やガソリンのような多成分燃料の蒸発噴霧につ いての研究は最近盛んに行なわれている。これまで噴 霧特性を実験的に調べる場合，主に噴射条件や霞囲気 条件に重点を置いた解析がなされていたが，Canaanら ${ }^{(10)}$ やSiebers ${ }^{(11)}$ は燃料の揮発性に着目し，ディーゼル噴 霧に扔ける液相の到達距離について調べている。また， 数值解析においては計算機の処理速度の向上により， これまで単一液滴の解析に用いられていた多成分燃料 蒸発モデルを噴第邪計算に組み込むまでに至っており， ディーゼル機関，ガソリン機関を問わずモデルの構築 がなされている。宮川ら ${ }^{(12)}$ は吸気管噴射ガソリン機関 を対象とした研究で，多成分燃料蒸発モデルを単一液 滴および実機の計算に適用し，ガソリンの蒸発挙動を 模擬するには少なくとも3成分を考虑した燃料を用い 
る必要があるとしている。Ayoubら (13)は多成分燃料蒸 発モデルを用いて，単一液滴ならびにディーゼル機関 における噴霧および然焼の計算を行なっている。 Lippertら (14)は軽油，ガソリンの然料組成を分布関数で 表し，単一液滴および噴霧に適用し，燃料に含まれる 揮発性の高い成分から蒸発することを示唆している。 また，Abrahamら (15)は多成分燃料液滴を同じ大きさの 単一成分より成る液滴に分割し, 計算の簡略化を図っ ている。しかし，これらのモデルには未だ不十分な点 も多く，例えば燃料が蒸発することによって時々刻々 と変化主る燃料成分の混合割合や雲囲気条件など詳細 な点までを考慮したモデルは考案されていない．

そこで本研究では多成分燃料の蒸発噴霧モデル(16)棈 築を目的とし，次章で述べる流れに沿って研究を進め る、本報ではその最初の段階として，まず，飽和温度 の異なる単一成分燃料を用いて計算を行ない, 蒸発挙 動の違いを明らかにすると共に, 噴霧内に生じる成分 ごとの空間分布を予測する。次に，噴霧が壁面に衝乫 する際，成分の飽和温度の違いによって沸騰形態が変 化し衝突挙動が異なることから，あらゆる沸騰形態に 適用できる壁面衝突モデルを提案する。

\section{2. 研究コンセプト}

本研究では，これまで構築した壁面衝突モデルをふ まえて, 今後多成分燃料噴霧へと展開するためのコン セプトを提案する。実際に機関で用いられる軽油は多 数の成分によって構成される多成分燃料であり，ガス クロマトグラフィーによる精密蒸留の結果によると， 蒸発が始まる初留点IBP（Initial Boiling Point）は 395[deg.], 終了する終留点FBP (Final Boiling Point)

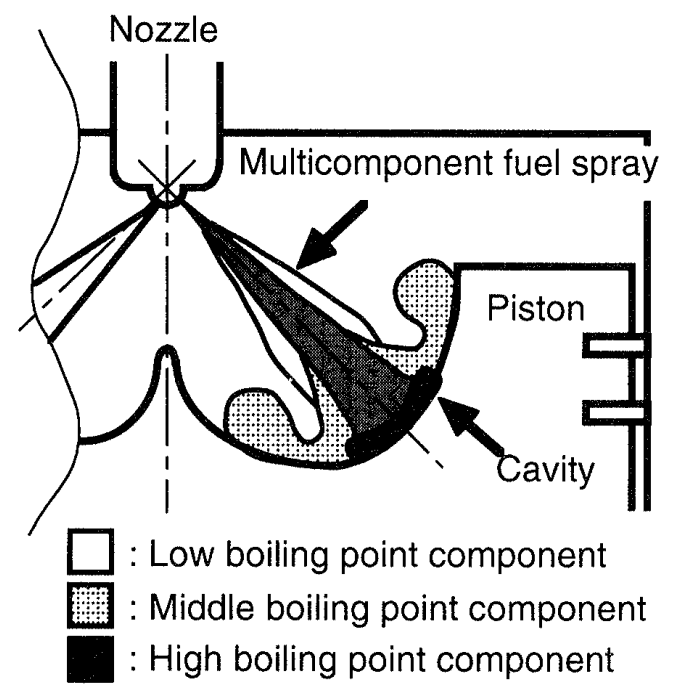

Fig.1 Model of vaporizing impinging diesel spray は681[deg.]となっており，両者の閒には290[deg.]程度 の開きがある。したがって，多成分燃料噴霧の場合， 図1のイメージ図に示すような成分分布が予測される。 飽和温度の低い成分は噴射開始直後にノズル近傍で蒸 発を開始し，一方飽和温度の高い成分は液相のまま壁 面に衝突して壁面上に液膜を形成する。また，その中 問の飽和温度を持つ成分は壁面近傍で蒸気を形成する。

そこで本研究では，図2の手順により多成分燃料噴 霧の蒸発挙動ならびに壁面衝突挙動のシミュレーショ ンを行なう。まず，最初の段階として，沸点の異なる 単一成分燃料を用いて同一噴射抢よび雾囲気条件で計 算を行ない，蒸発挙動の違いを明らかにすると共に， 沸騰形態の違いによる液滴一壁面干渉モデルを提案す
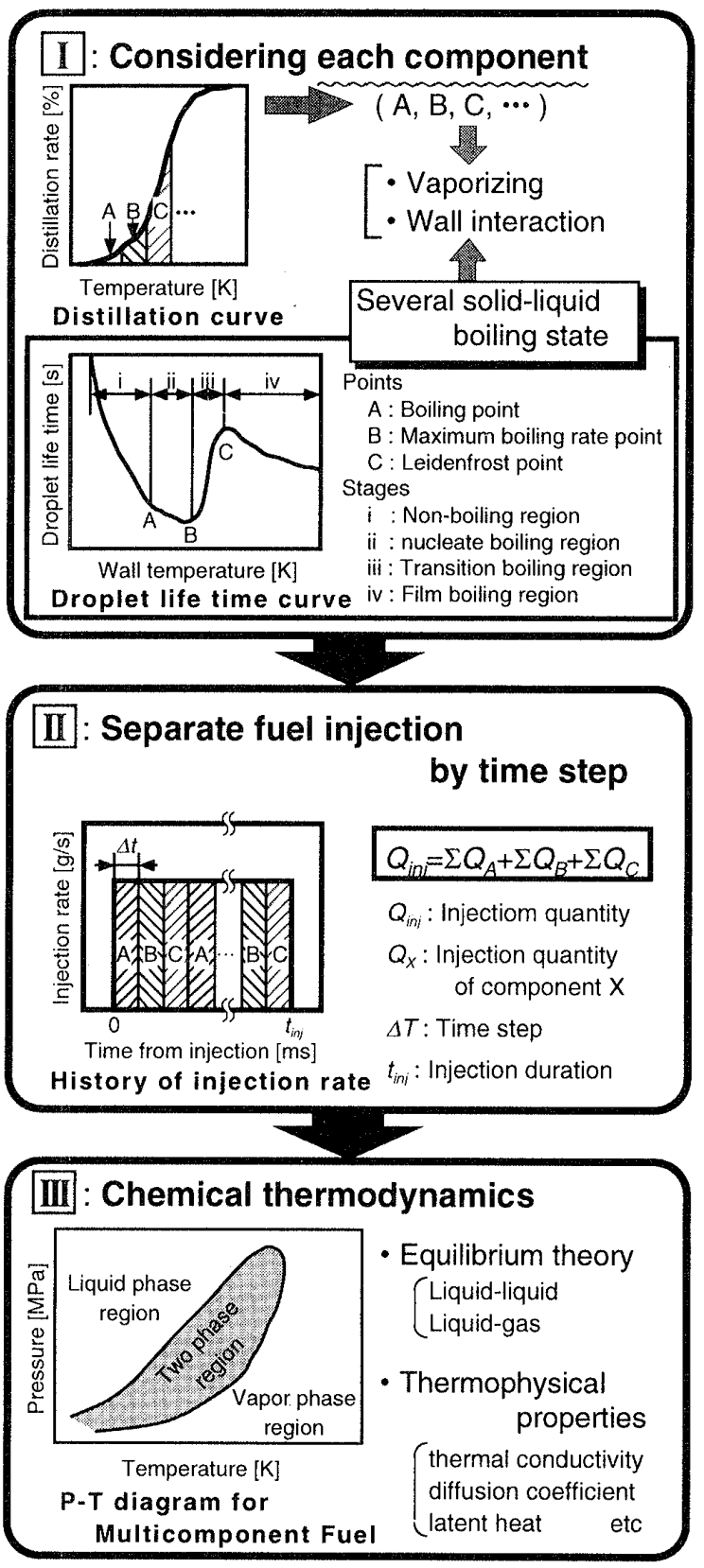

Fig.2 Flow chart of this study 
る。図 2 に示した壁面温度 $T_{w}$ に対する液滴寿命曲線は， 燃料の違いにより低沸点成分の場合は左へ，高沸点成 分の場合は右へシフトする。すなわち，燃料の違いは 同一壁面温度に対しても沸騰形態を変化させ，反射後 の分裂挙動（飛散角度, 液滴径, 速度) に影響を与え るため, 以前に提案した壁面衝突モデルの搪張を行な う. 次に，一回の噴射過程をタイムステップで分割し， それぞれに飽和温度 $T_{\text {sal }}$ の異なる数種類の燃料を噴射さ せることにより簡単な多成分燃料噴霧を形成させ，噴 霧構造における成分分布について解析する手法を提案 する。最終段階においては単一液滴の多成分燃料蒸発 モデル(16)を導入する。多成分燃料では四2に示すよう に圧力ー温度線図は，各成分の飽和蒸気曲線が互いに 引き寄せ合い，低沸点成分は高沸点成分に，高沸点成 分は低沸点成分に引っ張られ，ある幅を持つ二相領域 を形成する。このため，単一成分の場合と比べて気液 平衡の取り扱いが複雑となる。そこでこれらを考慮し た化学熱力学に基づく多成分然料蒸発モデルの構築を 行なう.

\section{3. 単一成分燃料噴霧の計算}

燃料性状を考慮するに当たり，燃料の違いが噴霧構 造にどのような影響を与えるかを知る必要がある。そ こで，燃料としてi-オクタン，n-トリデカン，n-ヘキサ デカンの沸点の異なる3成分を用いてKIVA-IIコードに より，同一条件の下で壁面衝突噴霧の計算を行なった。 これらの燃料性状を表1に，計算条件を表2に示す。こ こで，計算には筆者らの修正 TABモデル(17)および壁面 衝突モデル(9)を用いた。ただし，この壁面衝突モデル では, 液膜形成過程や液膜一液滴干涉過程は考慮され ているが，壁面過熱度の差異による壁面上液膜の分裂 挙動の変化は考慮されていない.

図3に噴射開始から $t=1.5[\mathrm{~ms}]$ のときの然料蒸気濃度 および液滴パーセルの空間分布を示す。図中の(a)はi一 オクタン，(b)はn-トリデカン，(c)はn一へキサデカンで ある。(a)のiーオクタンにおいては，最も沸点が低いた め噴射直後のノズル近傍から蒸発が始まり，噴霧中心 軸近傍掞よび壁面上に非常に濃度の高い蒸気が拡がっ ている。また，壁面にまで到達している液滴は極めて 少ないことから，液滴ではなく高濃度蒸気が噴霧を先 導して半径方向に拡がっていることが伺える。(b)のnトリデカンにおいては, 比較的濃度の高い蒸気が噴霧 中心軸および壁面近傍に拡がっている。(c)のn一ヘキ开 デカンにおいては, n-トリデカンに比べ蒸気濃度が低 くなって扔り，壁面上に多量の液滴が拡がっている。 また, 燃料蒸気よりも液滴パーセルの方が半径方向へ
Table 1 Fuel properties

\begin{tabular}{|c|c|c|c|c|}
\hline & & $\begin{array}{c}\text { i-Octane } \\
\left(\mathrm{C}_{8} \mathrm{H}_{18}\right)\end{array}$ & \begin{tabular}{c|}
$n$ n-Tridecane \\
$\left(\mathrm{C}_{13} \mathrm{H}_{28}\right)$ \\
\end{tabular} & $\begin{array}{c}n \text {-Hexadecane } \\
\left(\mathrm{C}_{16} \mathrm{H}_{34}\right) \\
\end{array}$ \\
\hline Boiling point & $T_{b}[\mathrm{~K}]$ & 372 & 509 & 560 \\
\hline Density (293K) & $\rho[\mathrm{kg} / \mathrm{m} 3]$ & 692 & 756 & 773 \\
\hline Critical pressure & $p_{c r}[\mathrm{MPa}]$ & 2.58 & 1.72 & 1.42 \\
\hline Critical temperature & $T_{c r}[\mathrm{~K}]$ & 569 & 677 & 725 \\
\hline Critical density & $\rho_{c t}\left[\mathrm{~kg} / \mathrm{m}^{3}\right]$ & 237 & 240 & 240 \\
\hline
\end{tabular}

Table 2 Computational conditions

\begin{tabular}{ll||c}
\hline Injection velocity & $V_{i n j}[\mathrm{~m} / \mathrm{s}]$ & 338 \\
\hline Injection duration & $t_{i n j}[\mathrm{~ms}]$ & 1.54 \\
\hline Injection quantity & $Q_{i n j}[\mathrm{mg}]$ & 12.0 \\
\hline Initial droplet temperature & $T_{p i}[\mathrm{~K}]$ & 293 \\
\hline Fuel & & i-Octane, $\mathrm{n}$-Tridecane, n-Hexadecane \\
\hline Number of parcel & $N_{p}$ & 1000 \\
\hline Ambient temperature & $T_{\mathrm{a}}[\mathrm{K}]$ & 700 \\
\hline Ambient density & $\rho_{\mathrm{a}}[\mathrm{kg} / \mathrm{m} 3]$ & 12.3 \\
\hline Wall temperature & $T_{\mathrm{w}}[\mathrm{K}]$ & 550 \\
\hline Impingement distance & $Z_{\mathrm{w}}[\mathrm{mm}]$ & 40 \\
\hline Impingement angle & $\alpha_{w}[\mathrm{deg}]$. & 0 \\
\hline Maximum time step & $d t_{\max }[\mathrm{s}]$ & $1.0 \times 10-6$ \\
\hline Minimum time step & $d t_{\min }[\mathrm{s}]$ & $0.5 \times 10-8$ \\
\hline Number of mesh & & $60 \times 1 \times 32$ (sector mesh) \\
\hline
\end{tabular}

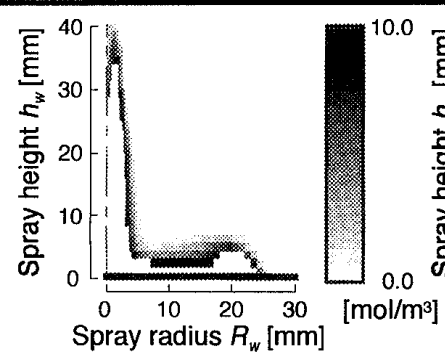

(a) i-Octane
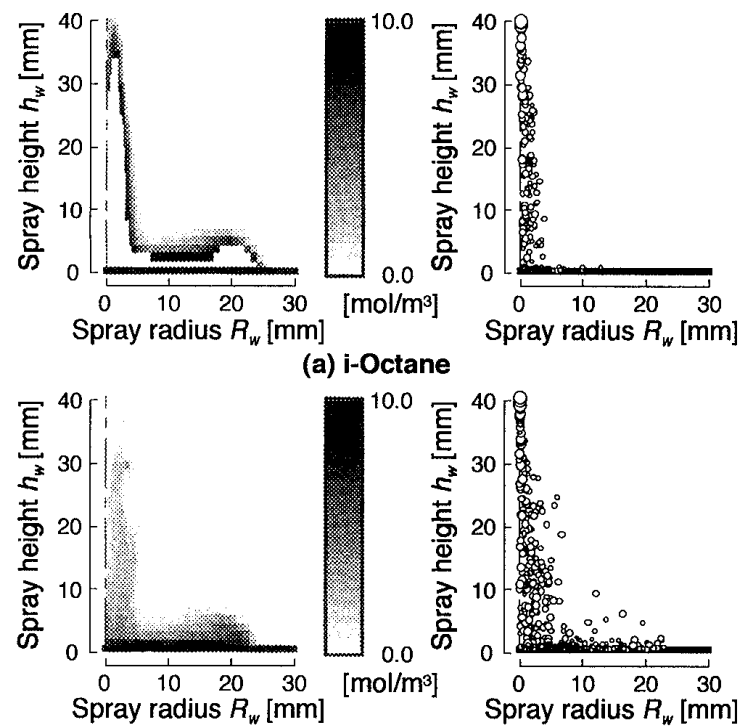

(b) n-Tridecane

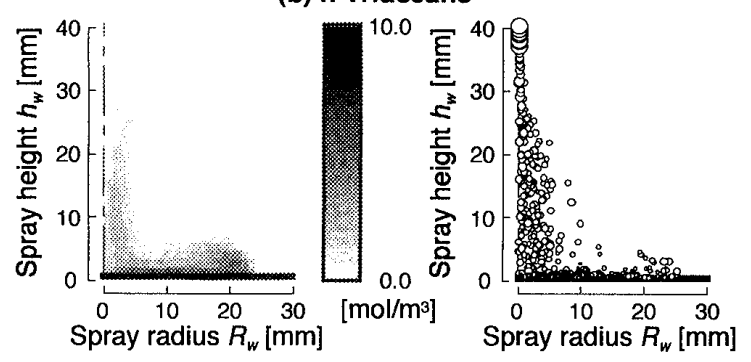

(c) n-Hexadecane
Distribution of vapor concentration
Distribution of droplet parcels
Fig.3 Comparison of spatial distribution of fuel vapor concentration and droplet parcels $(\mathrm{t}=1.5[\mathrm{~ms}])$




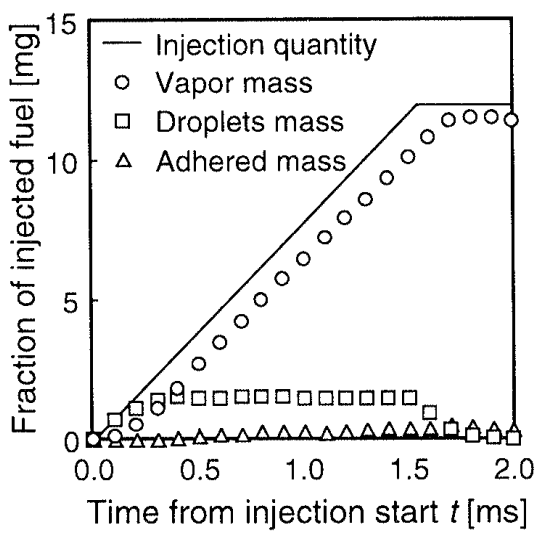

(a) i-Octane

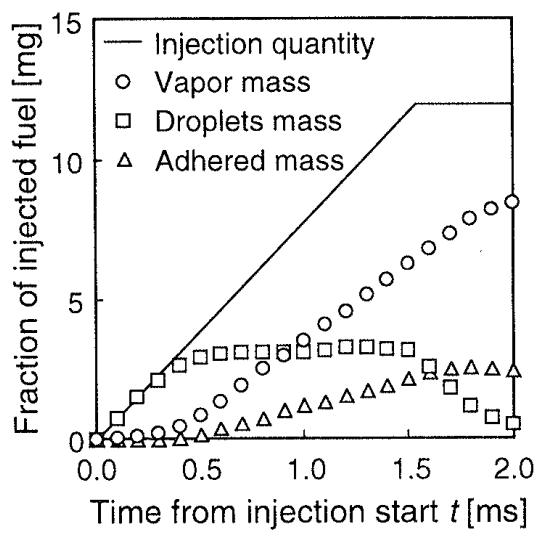

(b) $\mathrm{n}$-Tridecane

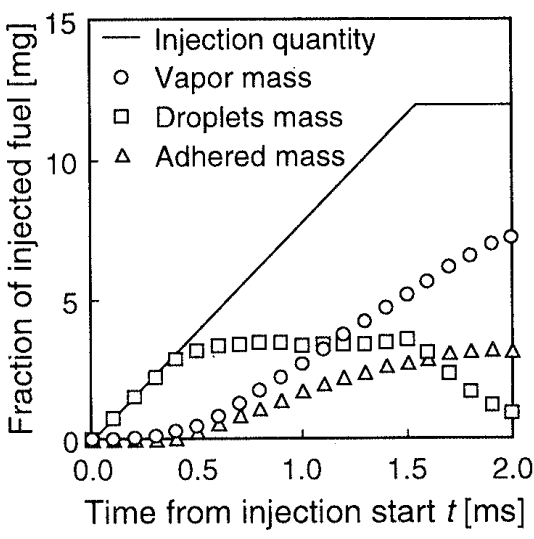

(c) n-Hexadecane

Fig.4 Temporal variations of fuel fraction in each phase

の拡がりが大きいことから，液滴がほとんど蒸発せず に壁面上を拡がり，その後壁面および雲囲気から熱を 受けて蒸発する様子が伺える。

図4にそれぞれの計算結果に扔ける噴射量，燃料蒸 気質量, 燃料液滴質量および壁面付着燃料量の時閪変 化を示す。この図からも燃料の違いによる蒸気量の差

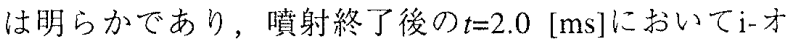
クタンの蒸気量が11.4[mg]と95[\%]が蒸発しているが, $\mathrm{n}$-ヘキサデカンの蒸気量は7.23 [mg]と約60[\%]程度し か蒸発していないことが分かる。

以上のことから，多成分燃料が噴射されると，図 1 のイメージ図に示したように噴霧内に揮発性に依存す る分布が生じると考えられる。そこで次章においては 様々な沸点を持つ成分が壁面に衝突した場合の異なる 沸騰形態に対応できる壁面衝突モデルの構築を行なう。

\section{4. 壁面衝突噴霧モデルの構築}

4・1 壁面過熟度による沸滕形態の変化 筆者 らは過去の研究(8)(9)に扔いて，高温壁面に衝突する水 滴の分裂形態に関する実験結果をもとに，壁面に衝突 する液滴の挙動をモデリングするには，壁面過熱度 $\Delta T_{s a t}$ （=壁面温度 $T_{w}$ - 液体の飽和温度 $T_{s a t}$ ）を考虑する 必要があることを提言してきた。

本研究で対象とする小型直噴式ディーゼル機関の壁 面温度範囲は，3〜6 [MPa]の加压条件下で473〜 673 [K] である。軽油の飽和温度にIBP，50[\%]留出温度，FBP をそれぞれとると，壁面過熱度の範讲は図5に示すよ うに-208〜278 [deg.] と非常に広くなる。すなわち, FBP に対しては $\Delta T_{\text {sat }}=-208 \sim-8$ [deg.]で非沸騰領域 $\left(\Delta T_{\text {sat }}<25\right.$ [deg.]），50[\%]留出温度に対しては $\Delta T_{\text {sut }}=-81 \sim 119$ [deg.] で非沸騰領域から核沸騰領域（ $\Delta T_{\text {sut }}=25 \sim 100$ [deg.]）, IBPに対しては $\Delta T_{s u t}=78 \sim 278$ [deg.]で主に遷移沸騰領域 $\left(\Delta T_{s a l}=100 \sim 200[\mathrm{deg}].\right)$ から膜沸騰領域 $\left(\Delta T_{s a t}=200 \sim\right.$
300 [deg.]）とあらゆる沸騰形態をとることになる。過 去の研究(8).(9)においては，n-トリデカンを代表成分と して用いたため，実機相当の高圧場では壁面過熱度は $\Delta T_{s a r}=-200 \sim 0$ [deg.] となり, 沸騰形態として非沸騰か ら核沸滕の条件しか考慮していなかった。しかし，多 成分然料である軽油を用いる場合，沸騰形態が遷移沸 騰および膜沸騰にまで及ぶために，固液界面の沸騰現 集に伴う液滴の種々の分裂形態を考慮する必要がある。

竹内らは単一水滴の高温壁面への衝突実験を行ない, 沸騰形態の違いによる液滴の挙動を示している。 ${ }^{(18)}$ れより，核沸騰においては液膜が形成され，分裂した 液滴は上方に吹き上げられるが，遷移沸騰，膜沸騰に おいては液膜は形成されず，分裂後の液滴は半径方向 に飛散することが分かる。したがって，核沸騰領域に 対しては参考文献(9)で提案したモデルは適用可能であ るが，遷移沸滕㧍よび膜沸騰領域には適用することが できない。そこで次節より图6に示した遷移沸騰，膜 沸騰に適用可能な壁㮌衝突モデルを提案する。

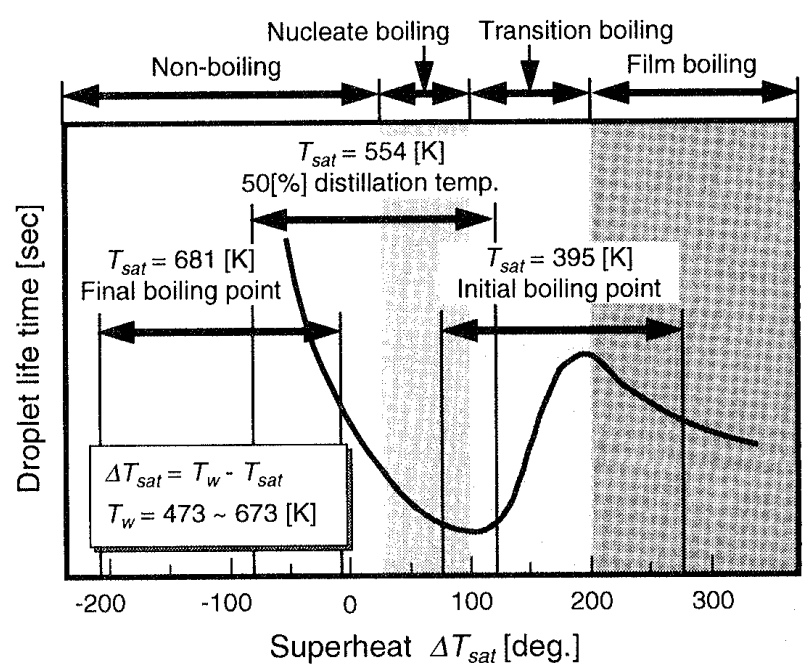

Fig. 5 Boiling curve of each composition in engine condition 


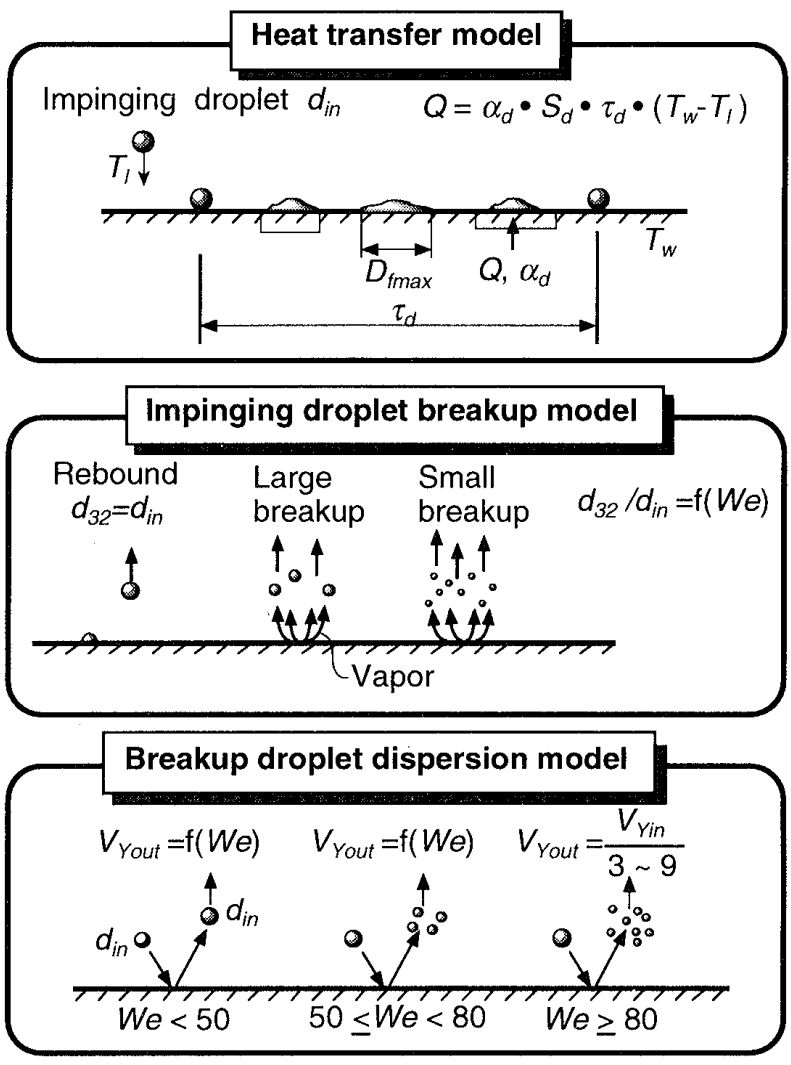

Fig.6 Spray impingement model on high - temperature wall

$4 \cdot 2$ 液滴分裂モデル 筆者らは以前に，高温壁 面に衝突する水滴の変形拉よび分裂挙動に関して，入 射液滴のWeber数 $W e_{i n}$, 壁面温度 $T_{w}$ を種々変化させて実 験を行なった(18) (20)。この中で, 液滴が壁面に衝突し, 壁面上を拡がる過程での固液界面における沸騰現象に よる分裂挙動と分裂後の液滴群のザウ夕平均粒径 $d_{32}$ が 入射液滴のWeber数 $W e_{\text {in }}$ と壁面温度 $T_{w}$ により整理できる ことを報告している。それによると，壁面衝突時の入 射液滴のWeber数 $W e_{\text {in }}$ が約 50 以下ならば液滴は分裂せ ず，それ以上では分裂する。さらに，Weber数が約 300 以上では分裂液滴群の平均粒径は一定値に漸近する。

図7は液滴径 $d_{i n}=450[\mu \mathrm{m}]$, 衝突速度 $V_{i n}=5.0[\mathrm{~m} / \mathrm{s}]$ の水 滴が壁面に垂直に衝突する場合の壁面過熱度 $\Delta T_{s a t}$ と分

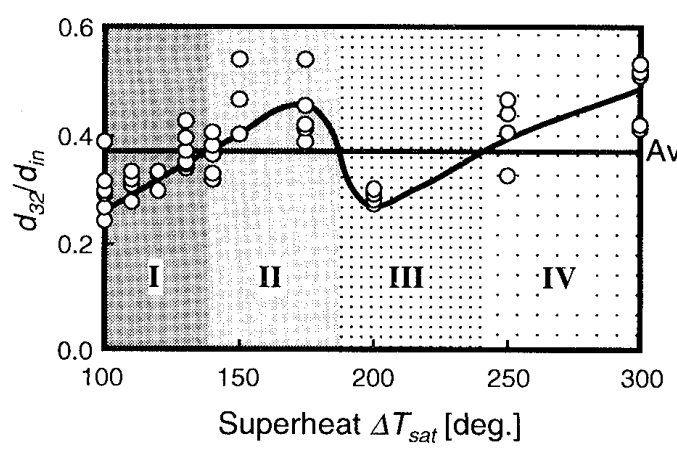

Fig.7 Variation in Sauter mean diameter of breakup droplets with super heat
裂前後の液滴径の比 $d_{32} / d_{i n}$ の関係を示したものである (18). 図7より，各デー夕の平均值である0.37をもとに壁 面過熱度 $\Delta T_{s a l}=100 \sim 300$ [deg.]の領域をI～IVの $4 つ の$ 領 域に分割し，同一領域内においては沸騰現象による分 裂挙動が定性的に一致するとする。

また，竹内らの実験結果より ${ }^{(18)}$, 衝突後の分裂液滴 の平均粒径 $d_{32}$ を入射Weber数 $W e_{i n}$ の関数としてそれぞ れ式(1)〜(4)で近似する。これにより，各沸騰形態にお ける液滴の分裂後のザウタ平均粒径が算定可能となる.

·領域I $\left(\Delta T_{\text {sat }}=100 \sim 140[\mathrm{deg}].\right)$

$W e_{\text {in }}<50: d_{32}=d_{\text {in }}$

$50 \leq W e_{i n}<140: d_{32}=\left(1.07-1.01 \times 10^{-2} \times W e_{i n}\right.$ $\left.+3.29 \times 10^{-5} \times W e_{i n}{ }^{2}\right) \times d_{i n}$ $140 \leq W e_{i n}<300: d_{32}=0.416 \times 10^{\left(-1.02 \times 10^{-3} \times W_{e_{i n}}\right)} \times d_{\text {in }}$ $300 \leq W e_{i n}: d 32=0.2 \times d_{i n}$

·領域II $\left(\Delta T_{\text {sat }}=140 \sim 190\right.$ [deg.] $)$

$W e_{i n}<50: d_{32}=d_{i n}$

$50 \leq d_{32}<160: d_{32}=1.37 \times 10^{\left(-3.13 \times 10^{-3} \times W \epsilon_{i n}\right)} \times d_{i n}$ $160 \leq W e_{i n}<300: d_{32}=0.558 \times 10^{\left(-9.30 \times 10^{-3} \times W e_{\text {en }}\right)} \times d_{i n}$ $300 \leq W e_{i n}: d_{32}=0.3 \times d_{i n}$

- 領域III $\left(\Delta T_{\text {sat }}=190 \sim 240[\mathrm{deg}].\right)$

$W e_{i n}<50: d_{32}=d_{\text {in }}$

$50 \leq W e_{i n}<140: d_{32}=\left(2.60-3.17 \times 10^{-2} \times W e_{i n}\right.$ $\left.+1.12 \times 10^{-4} \times W e_{i n}^{2}\right) \times d_{i n}$

$140 \leq W e_{i n}<300: d_{32}=0.687 \times 10^{\left(-1.92 \times 10^{-3} \times W e_{\text {in }}\right)} \times d_{i n}$ $300 \leq W e_{i n}: d_{32}=0.2 \times d_{i n}$

·領域IV $\left(\Delta T_{\text {sat }}>240\right.$ [deg.] $)$

$W e_{i n}<50: d_{32}=d_{i n}$

$50 \leq W e_{i n}<190: d_{32}=\left(1.34-6.66 \times 10^{-3} \times W e_{i n}\right.$ $\left.+8.19 \times 10^{-6} \times W e_{i n}^{2}\right) \times d_{i n}$ $190 \leq W e_{i n}<300: d_{32}=0.753 \times 10^{\left(-1.55 \times 10^{-3} \times W e_{i n}\right)} \times d_{i n}$ $300 \leq W e_{i n}: d_{32}=0.3 \times d_{i n}$

ただし $50 \leqq W e_{i n}<300$ の条件において，各式で $d_{32}>d_{i n}$ となる場合は $d_{32}=d_{i n}$, 式(1), (3)で $d_{32}<0.2 \times d_{i n}$, 式(2), (4) で $d_{32}<0.3 \times d_{i n}$ となる場合は，それぞれ $d_{32}=0.2 \times d_{i n}$, $d_{32}=0.3 \times d_{i n}$ とする.

$4 \cdot 3$ 液滴反射モデル Wachtersら ${ }^{(21)}$ は高温壁面 $\left(\mathrm{T}_{\mathrm{w}}=400\left[{ }^{\circ} \mathrm{C}\right]\right)$ に衝突する膜沸騰状態の水滴の実験を 行ない, 液滴のWeber数がその反射挙動に影響を与え る重要な因子であるとしている。Naberら(22)はこれら の実験から入射時と反射時の液滴のWeber数の関係を 定式化し，その結果を用いて壁面衝突後の液滴の垂直 
方向の速度成分を決定できる反射モデルを考案してい る。図8はNaberらによって提案された液滴反射モデル である．図8の関係より，反射時の液滴のWeber数W $e_{\text {out }}$ は, 入射時のWeber数 $W e_{i n}$ の関数として次式で近似さ れる。

$$
W e_{\text {rut }}=0.678 \times W e_{\text {in }} \times \operatorname{Exp}\left(-4.415 \times 10^{-2} \times W e_{\text {in }}\right)
$$

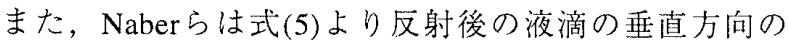
速度成分 $V_{Y o u t}$ を次式で表している。

$$
\left.\begin{array}{l}
W e_{\text {in }}<80: V_{Y_{\text {out }}}=-\left(W e_{\text {out }} \frac{\sigma}{\rho_{f} \cdot d_{\text {in }}}\right)^{1 / 2} \\
W e_{\text {in }} \geq 80: V_{Y_{\text {out }}}=0
\end{array}\right\}
$$

ここで， $\sigma$ は表面張力 $[\mathrm{N} / \mathrm{m}] ， \rho_{f}$ は燃料の密度 $\left[\mathrm{kg} / \mathrm{m}^{3}\right]$ で ある。

しかし，このモデルを用いて計算を行なうと，壁面 に衝突したほとんどの液滴がwall jetとして壁面上を搪 がってしまう。これは，ディーゼル噴㦻においては壁 面に衝突する液滴のWeber数が非常に高いため，ほと んどの液滴の垂直方向の反射速度が $V_{Y_{\text {out }}}=0$ として計算 されるためである。そこで本研究では，以前に提案し た高温壁面衝突モデル(7)と同様に，We $e_{i n}<80$ では式(6) の関係を用い, $W e_{i n} \geqq 80$ では高温壁面に衝突する水滴 の挙動を観察した過去の研究(18) (20)を参考にし，反射時 の速度 $V_{Y o u r}$ を求める. それによると，高Weber数では壁 面に衝突し分裂した液滴は，入射速度 $V_{Y i n}$ の1/3〜1/9の

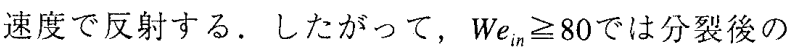
液滴径などに関わらず入射速度 $V_{Y i n}$ の $1 / 3 \sim 1 / 9$ の值で反 射速度 $V_{Y o u t}$ をランダムに割り振る。これにより，本研 究で考慮した壁面からの反射速度 $V_{Y o u t}$ は次式(7)のよう になる。

$$
\left.\begin{array}{l}
W e_{\text {in }}<80: V_{\text {Yout }}=-\left(W e_{\text {out }} \frac{\sigma}{\rho_{f} \cdot d_{i n}}\right)^{1 / 2} \\
W e_{\text {in }} \geq 80: V_{\text {Yout }}=V_{\text {Yin }} / \gamma
\end{array}\right\} \cdots
$$

ここで $\gamma$ 3〜90值をとる乱数である。

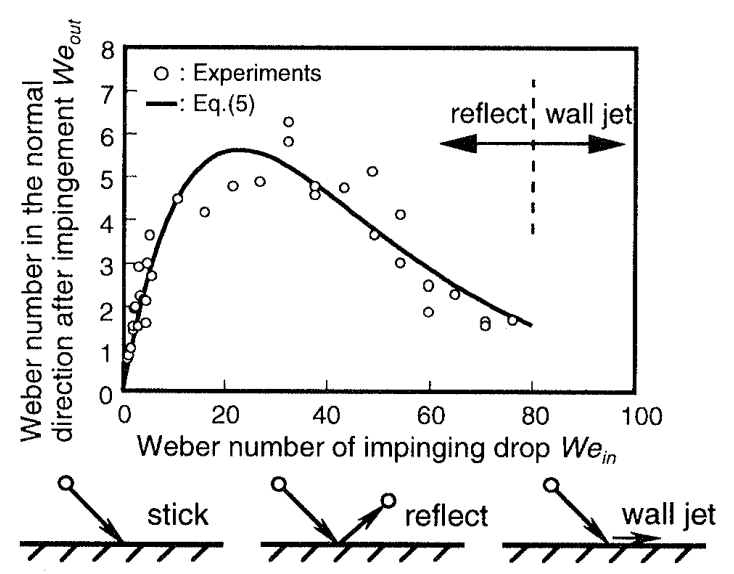

Fig.8 Spray impingement model by Naber \& Reitz
4 -4 壁面熱伝達モデル 高温壁面に衝突した液 滴は，図6に示すようにある一定期間壁面上で液膜状 に拡がり，その後収縮し，分裂あるいは未分裂の状態 で壁面より反射する。ノズルより噴射された燃料夜滴 の温度は，䨌囲気の高温気体加らの熱供給により上昇 するが，衝突時の液滴温度 $T_{l}[\mathrm{~K}]$ は壁面温度 $T_{w}[\mathrm{~K}]$ より も低く，壁面から液滴への熱伝達が生じる。壁面より 供給された熱量は，液滴が壁面上に滞留している間， 液滴の温度上昇および蒸発過程に費やされる。壁面か ら液滴への熱伝達量 $Q[\mathrm{~J}]$ は, 式(8)で与えられる。

$$
Q=\alpha_{d} \cdot S_{d} \cdot \tau_{d} \cdot \Delta T
$$

ここで, $\alpha_{d}$ : 壁面から液滴への熱伝達率 $\left[\mathrm{W} /\left(\mathrm{m}^{2} \cdot \mathrm{K}\right)\right], S_{d}$ : 壁面と液滴との接触面積 $\left[\mathrm{m}^{2}\right], \tau_{d}$ : 液滴の壁面上での 滞留時間 $[\mathrm{s}], \Delta T$ : 壁面温度 $T_{w}$ と液滴温度 $T_{l}$ の温度差 $\left(=T_{w}\right.$ - $\left.T_{i}\right)[\mathrm{K}]$ であるこの熱量が全て液滴の温度上昇に使 われたとすると，液滴の上昇温度 $\Delta T_{l}[\mathrm{~K}]$ は，液滴の質 量 $M[\mathrm{~kg}]$, 液滴の比熱 $C_{p}[\mathrm{~J} /(\mathrm{kg} \cdot \mathrm{K})]$ を用いて次式で表せ る.

$$
\Delta T_{i}=\frac{Q}{M \cdot C_{p}}=\frac{\alpha_{d} \cdot S_{d} \cdot \tau_{d} \cdot \Delta T}{M \cdot C_{p}}
$$

式(9)の未知数 $\alpha_{d} ， S_{d} ， \tau_{d}$ を決定することにより，壁 面からの熱伝達による液滴の上昇温度 $\Delta \mathrm{T}_{1}[\mathrm{~K}]$ が算出可 能となる. 以下, 未知数 $\alpha_{d}, S_{d}, \tau_{d}$ の求め方について 説明する.

4·4・ 1 熱伝達率 $\alpha_{d}$ 壁面加ら液滴への熱伝達率 は, 衝突時の液滴速度や液滴径さらに壁面温度などの 状態によって変化するが，それらに関して詳細に調べ た研究例は少なく定式化されていない。筆者ら ${ }^{(20)} は$, 高温壁面に衝突する水滴の熱伝達特性に関する研究を 行なっており，図9に示すように衝突頻度をパラメー 夕として熱伝達率 $\alpha_{d}$ と壁面過熱度 $\Delta T_{s a t}$ の関係について 調べている。この場合の試料は対象とする炭化水素系 燃料と買なるが，液滴の壁面衝突挙動が壁面過熱度に

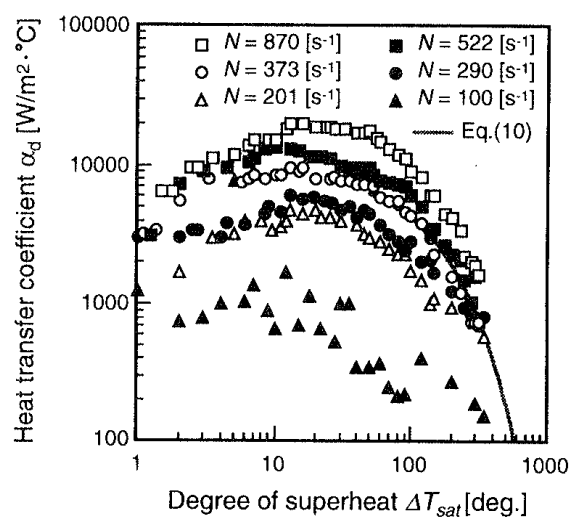

Fig. 9 Change in heat transfer coefficient with super heat 
よって整理されると考え, 本研究ではこの実験結果を 用いる。本モデルの対象は $\Delta T_{s a t}=100$ [deg.] 以上の遷移 沸騰および膜沸騰である。そこで，図9において各衝 突頻度で熱伝達率 $\alpha_{d}$ が減少し始める $\Delta T_{s u t}=50$ [deg.] 以上 の全データを次式で近似する。

$$
\alpha_{d}=9084 \times 10^{-0.003 \cdot \Delta T_{s t t}}
$$

これにより，計算条件で設定される壁面過熱度 $\Delta T_{s a t} に$ おける熱伝達率 $\alpha_{d}$ が決定される。

$\mathbf{4} \cdot \mathbf{4} \cdot \mathbf{2}$ 壁面滞留時間 $\tau_{d}$ 壁面上での液滴の滞留 時間 $\tau_{\mathrm{d}}$ について, 大久保 ${ }^{(24)}$ は佐藤ら ${ }^{(25)}$ の最大液膜径 $D_{\text {fmax }}$ に達する時間 $\tau_{\text {mux }}$ を用いて次式で表している。

$$
\begin{aligned}
& \tau_{d}=a \cdot \tau_{\max } \\
& \tau_{\text {max }}=0.27 \cdot \tau_{r}
\end{aligned}
$$

ただし， $a$ は非分裂の場合に $a=1 / 0.27$ ，分裂する場合に $a=0.6 / 0.27$ をる定数である。また， $\tau_{r}$ はRayleigh ${ }^{(26)} の$ 自由振動第一モード周期であり，次式で表される.

$$
\tau_{r}=\pi \cdot\left\{\rho_{f} \cdot d_{i n}{ }^{3} /(16 \cdot \sigma)\right\}^{1 / 2}
$$

一方, 筆者らが以前に提案したモデル(7)においては, 高温壁面に衝突する液滴の挙動を高速度カメラで撮影 した過去の研究(18) (20)より判断し, $W e_{i n}<80$ では, 滞留 時間 $\tau_{d}=\tau_{r}, W e_{i n} \geqq 80$ では, $\tau_{d}=\tau, / 2$ とし, 計算を行なっ ている.

そこで本研究においては，参考文献(7)をふまえて式 (11)において $W e_{i n}<80$ では $a=1 / 0.27, W e_{i n} \geqq 80$ では $a=0.5 / 0.27$ として, 液滴の壁面滞留時間 $\tau_{d}$ を次式で与え t.

$$
\left.\begin{array}{l}
W e_{i n}<80: \tau_{d}=\tau_{r}=\pi \cdot\left\{\rho_{f} \cdot d_{i n}{ }^{3} /(16 \cdot \sigma)\right\}^{1 / 2} \\
W e_{i n} \geq 80: \tau_{d}=0.5 \cdot \tau_{r}=\pi \cdot\left\{\rho_{f} \cdot d_{i n}{ }^{3} /(64 \cdot \sigma)\right\}^{1 / 2}
\end{array}\right\}
$$

ただし，本研究では計算を簡略化するため，衝突した 液滴は滞留時間の間壁面上に留まるのではなく，1夕 イムステップで反射し, 熱量だけが滞留時間中に加え られるものとしている。

$\mathbf{4} \cdot \mathbf{4} \cdot \mathbf{3}$ 接触面積 $S_{d}$ 筆者ら ${ }^{(19)}$ は, 高温壁面に衝 突する液滴の変形挙動の解析において, 液面上で拡が った液膜の最大直径 $D_{f m u x}$ は入射時のWeber数 $W e_{i n}$ の関数 となるとしている。これによると，壁面過熱度 $\Delta T_{s a t}$ が $100,150,200,300[\mathrm{deg}$.$] の場合, 液膜の最大直径 D_{\text {fmax }}$ は次式で与えられる。

$$
\begin{aligned}
& \Delta T_{\text {sat }}=100 \text { [deg.] }: D_{\text {fmax }}=\left(1+0.463 \cdot W e_{i n}^{0.345}\right) \times d_{i n} \\
& \Delta T_{\text {sat }}=150 \text { [deg.] }: D_{\text {fmax }}=\left(1+0.279 \cdot W e_{i n}^{0.473}\right) \times d_{i n} \\
& \Delta T_{\text {sat }}=200\left[\text { deg.] }: D_{\text {fmax }}=\left(1+0.245 \cdot W e_{i n}^{0.503}\right) \times d_{i n}\right. \\
& \Delta T_{\text {sat }}=300 \text { [deg.] }: D_{\text {fmax }}=\left(1+0.153 \cdot W e_{i n}^{0.591}\right) \times d_{i n}
\end{aligned}
$$

過去に構築したモデル(6).(7)においては, 液膜の最大 直径 $D_{\text {fmax }}$ より簡易的に液滴の接触面積を求めていたが, 液滴が壁面に接触してから離れるまでの間，接触して いる面積が $S_{d=}=\pi \cdot D_{\text {fmax }}{ }^{2} / 4$ で一定となり，壁面より受け る熱量を過大に見積もってしまう，そこで本研究では， 大久保 ${ }^{(24)}$ の一個の液滴による時間平均被覆面積 $A_{d, m}$ を 用いて，液滴が壁面に接触してからリバウンドするま での平均接触面積 $S_{d}$ を次式で表す.

$$
S_{d}=A_{d, m}=\left\{\frac{3}{20}-\frac{5}{4}\left(a^{-0.2}-1\right)\right\} \cdot \frac{\pi \cdot D_{\text {fmax }}^{2}}{a}
$$

ここで，aは前項と同様に, $W e_{i n}<80$ では $a=1 / 0.27, W e_{i n}$

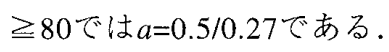

\section{5. 壁面衝突噴霧の計算}

$5 \cdot 1$ 計算条件噴射条件は表 2 と同様であるが， 衝突距離 $Z_{w}=30[\mathrm{~mm}]$, 壁面温度 $T_{w}$ を560, 660,760[K] とした。また，然料はn-トリデカンである。この場合， 壁面過熱度はそれぞれ $\Delta T_{s a t}=50 ， 150 ， 250$ [deg.] となり， 固液界面での沸騰現象はそれぞれ核沸騰，遷移沸騰， 膜沸騰となる。

$5 \cdot 2$ 計算結果 図10に噴射開始から $t=1.5[\mathrm{~ms}]$ のと きの燃料蒸気濃度および液滴パーセルの空間分布を示 す。（a)はオリジナルコードによる計算結果，(b)，(c)， (d)はそれぞれ核沸騰, 遷移沸騰, 膜沸騰の場合の計算 結果である。オリジナルコードの場合，壁面からの熱 伝達が考慮されておらず，各壁面温度による計算結果 が同等のものとなったため，一つの結果のみを示した。

困10において，(a)では壁面からの熱伝達が考慮され ていないこと, 噴霧の壁面衝突挙動が詳細に記述され ていないことから，蒸気濃度分布が非常に希薄なもの となっており，壁面上の液滴も比較的大きいことが分 かる、核沸騰の条件で計算された(b)では，液膜形成モ デル(8)(19)が適用されて扔り，液滴分布から，壁面上に 厚みを持った液膜が形成されている様子が伺える。さ らに，遷移沸騰，膜沸騰の条件で計算された(c), (d)で は，壁面上に非常に高濃度の蒸気が形成されており(壁 面上の白色部分は蒸気濃度が $10\left[\mathrm{~mol} / \mathrm{m}^{3}\right]$ 以上である), 液膜を形成せず液滴が飛散するという両沸騰形態の挙 動が記述されていることが分かる。

図11は各計算結果での燃料蒸気質量の時間変化を示 している。この図より，壁面温度が上昇するほど蒸気 の形成が活発になることが伺える. 膜沸騰より遷移沸 騰の方が壁面衝突後の液滴径は小さく，熱伝達率は大 きいが，壁面と液滴との温度差は膜沸騰の方が大きい ため, 結果として膜沸騰の方が蒸気量が多くなったと 考えられる。 

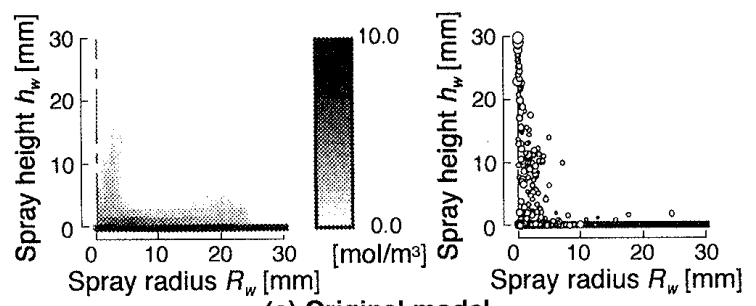

(a) Original model
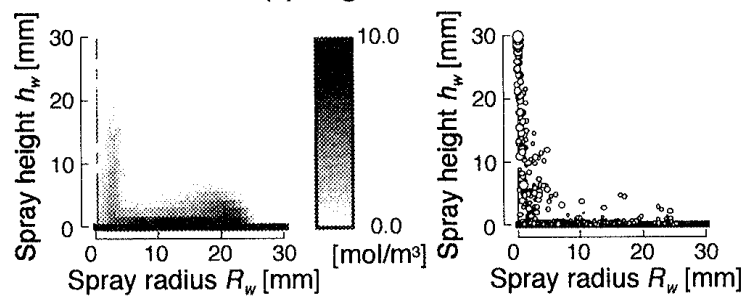

(b) Nucleate boiling state $\left(\Delta T_{\text {sat }}=50\right.$ [deg.]
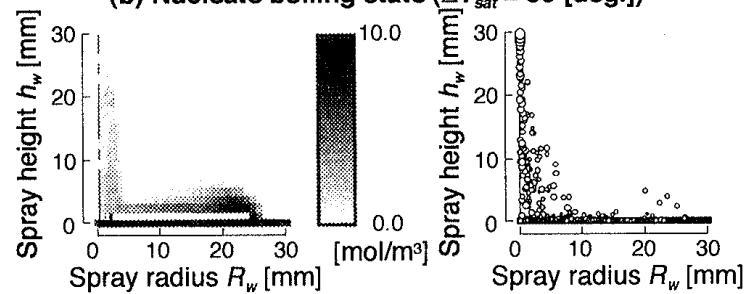

(c) Transition boiling state $\left(\Delta T_{\text {sat }}=150\right.$ [deg.] $)$
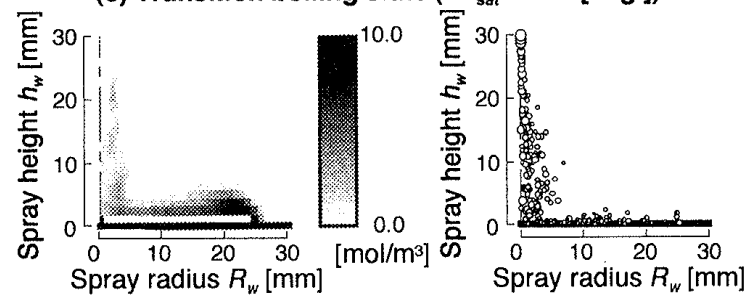

(d) Film boiling state $\left(\Delta T_{\text {sat }}=250\right.$ [deg.])
Distribution of vapor concentration
Distribution of droplet parcel
Fig.10 Comparison of spatial distribution of fuel vapor concentration and droplet parcels $(t=1.5[\mathrm{~ms}])$

\section{6. 結言}

多成分燃料噴霧のモデリングに当たり，その第一段 階として然料成分の違いによる噴霧への影響について シミュレーションを行ない，噴霧内に生じると予測さ れる成分分布について示した。次に，然料成分の違い によって同一温度の壁面に衝笑した場合に，固液界闻 で生じる沸騰形態の変化を示唆し，それらの現象を詳 細に記述した壁面衝突モデルの構築を行なった。これ により，オリジナルコードでは壁面温度に関わらず同 等とされていた液滴の壁面衝突現象を, 本研究のモデ ルを用いることによって，より広範䎴の液滴の沸騰現 象を扱うことができるようになった。

本報で提案したモデルにおいては，あらゆる燃料の 沸騰現象が壁面過熱度で整理できることから，ディー ゼル機関のみでなく，筒内直接噴射式ガソリン機関の

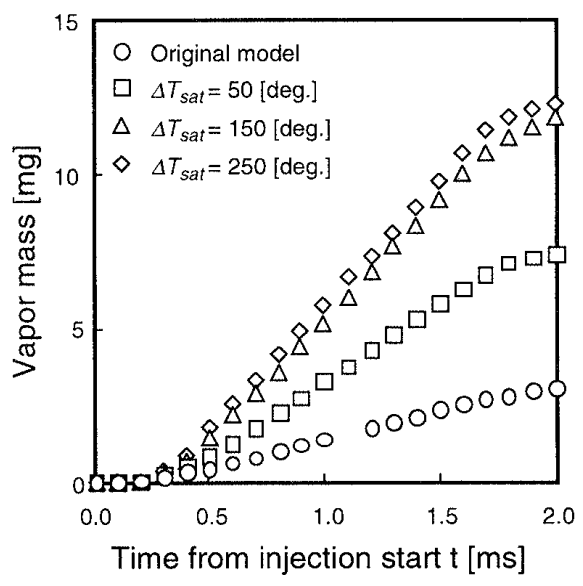

Fig.11 Temporal change in fuel vapor mass

噴霧に対しても適用可能である。

本研究の一部は，ダイハツ工業（株）および日本機 械学会研究分科会RC163の補助によって行なわれた。 ここに記して謝意を表す。

\section{参考文献}

（1）例えば, 千田, 岩下, 會橋, 斎藤, 藤本, 自技論, Vol.25.No.2, (1994), pp.76-81.

(2) 千田, 神田，小林，由邊，藤本，機論，63-607(B)，(1997), pp.323327.

（3）神田，千田，小林，田邀，藤本，機論，63-607(B)，(1997)，pp.328333.

(4) Amsden, A. A., Ramshow, J.D., O'Rourke,P. I. and Dukowicz, J.K, Los Alamos National Laboratory report, LA-10254-MS, (1985).

(5) Amsden, A. A., O'Rourke,P. I. and Butler, T. D., Los Alamos National Laboratory report, (1987).

(6) 千四, 小林, 岩下, 藤本, 機論, 60-578(B), (1994), pp.3563-3570.

(7) Senda, J., Kobayashi, M., Iwashita, S. and Fujimoto, H., SAE Paper, No.941894, (1994).

(8) Senda, J., Kanda, T., Al-Roub, M., Farrell,P. V. , Fukami, T. and Fujimoto, H., SAEPaper, No.970047, (1997).

(9) 千开, 神田, 草野, 藤本, 機綸65-629(B), (1999), pp.389-396.

(10) Canaan, R. E., Dec, J. E., Green, R. M. and Daly, D. T., SAE Paper, No.980510, (1998).

(11) Siebers, D. L., SAEPaper, No.980809, (1998).

(12) 宫川, 永嗍, 大澤, l把, 自技会講演前刷集, No.971, (1997), pp.321-324.

(13) Ayoub, N. S. and Reitz, R. D., SAEPaper, No.950285，(1995).

(14) Lippert, A. M. and Reitz, R. D., SAEPaper, No.972882, (1997).

(15) Abraham, J. and Magi, V., SAE Paper, No.98051 1， (1998).

(16)千田, 檜垣，高橋，高木，足立，藤本，機論投稿中

(17) Senda, J., Dan, T., Takagishi, S., Kanda, T. and Fujimoto, H., The 7th Int. Conf. Liquid and Spray Systems (ICLASS-97), (1997), pp.149-156.

(18) 竹内, 千田, 佐藤, 内燃機関, 21-268, (1982), pp.9-18.

(19) 千터，山田，竹内，三木，機論，52-481(B)，(1986), pp.3372-3379.

(20) 千田，山田，藤本，三水，機論，53-485(B)，(1987), pp.176-182.

(21) Watchers, L. H. J. and Westerling, N. A. J., Chem. Eng. Sic., Vol.21, (1966), pp.1047-1057.

(22) Naber, J.D. and Reitz, R. D., SAE Paper, No.880107， (1988).

(23) Naber, J.D., Enright, B. and Farrell, P., SAE Paper, No.881316, (1988).

(24) 大久保, 生産研究，46-12，(1994)，pp.635-642.

(25) 佐藤，鈴木，德成，機論，51-465(B)，(1985), pp.1703-1711.

(26) Rayleigh, L., Proc R. Soc., 29, (1879), 71. 